\title{
Entrepreneurial skill development: Participatory action research approach in a rural community
}

\author{
Maria J Botha, Maria E van der Merwe, Alté Bester \& Ruth M Albertyn
}

\begin{abstract}
Opsomming
Entrepreneurskap, bemagtiging en opleiding word deur die regering aangemoedig om die dringende probleme van armoede en werkloosheid in plattelandse areas van Suid-Afrika aan te spreek. Volwassene-onderrig en sosiale intervensie programme kan as middele benut word om die verlangde vaardighede te ontwikkel en toepaslike kennis op te doen. Volwassene opvoeders, navorsers en beplanners het erken dat dit belangrik is om die armes te betrek in enige program wat ten doel het om armoede te verlig en lewenstandaard te verbeter.
\end{abstract}

Hierdie navorsing het op die ontwikkeling van entrepreneurskap in die plattelandse dorp van Darling (Suid-Afrika) gefokus deur die toepassing van 'n volwassene-onderrig program. 'n Deelnemende-aksienavorsingsbenadering (Participatory Action Research - PAR) is gevolg met die fasilitering van die DARE (Development and Advancement of Rural Entrepreneurship) program deur die Departement Verbruikerswetenskap van die Universiteit van Stellenbosch. PAR is ' $n$ sistematiese navorsingsmetode en bestaan uit ' $n$ siklus van vier prosesse naamlik, beplanning, aksie, observasie en besinning wat siklies herhaal. Gegewens word hierdeur ingesamel terwyl deurlopende terugvoering aan die deelnemers verskaf word. PAR is toegepas as ' $n$ strategie om bemagtiging te fasilititeer by die deelnemers aan die program terwyl hul entrepreneursvaardighede ontwikkel.

Die navorsing het oor ' $\mathrm{n}$ tydperk van 15 maande geskied. Die data-insamelingstegnieke wat toegepas is, was onderhoude, observasie en ' $n$ vraelys (Albertyn's Empowerment Questionnaire) wat kwalitatiewe en kwantitatiewe gegewens opgelewer het. Nadat die behoeftes van potensiële deelnemers bepaal is, is 20 gewillige deelnemers in drie aksiegroepe blootgestel aan 'n intervensie van opleiding in entrepreneurs vaardighede (Snowflake Bake for Profit). Elke kursus het bestaan uit drie teoretiese sessies oor besigheidsvaardighede en drie praktiese sessies om bakvaardigheid te ontwikkel oor 'n tydperk van ses weke. Die teoretiese en praktiese sessies is alternatief aangebied. Die PAR-proses is deur die verdere verloop van die navorsingstydperk toegepas en die proses van implementering is gemonitor.

Kulminerende evaluering het die assessering van bemagtiging en die toepassing van entrepreneuriese vaardighede behels. Die vooraf- en hertoetsing ontwerp is benut vir die meet van bemagtiging. Die vraelys (Albertyn's Empowerment Questionnaire) meet bemagtiging op drie vlakke, naamlik mikrovlak (persoonlik), interpersoonlike vlak en makrovlak (sosio-polities). Semi-gesktruktureerde onderhoude na afloop van die kursus het as kulminerende evaluering van die entrepreneuriese vaardighede gedien.
Die bevindings toon dat die belangegroep die behoefte aan voorsiening van opleiding vir vaardigheidsontwikkeling met die oog op inkomstegenerering binne toerisme in Darling, potensiaal het. Die meerderheid van die deelnemers, wat vrywillig deel van die teikengroep was, was werklose vrouens tussen die ouderdomme 19 - 58 jaar. Geen groepslede was voorheen aan entrepreneurskapsopleiding blootgestel nie. Na afloop van die Snowflake Bake for Profit kursus is die groepslede in die teikengroep opgeneem om ander projekte te beplan en te implementeer. Die siklusse van beplanning, aksie, observasie en besinning is gevolg en verskeie verdere aksies is onderneem soos die verkope by die Darling Focus vakansieprojek en die opleiding van die Darling Focus komitee. Die projekte is gemonitor deur hierdie siklusse te dokumenteer en oor hulle te besin.

Die evaluering van die bemagtigingstatus van die kursusdeelnemers het getoon dat daar ' $n$ verbetering in die totale bemagtigingstatus na afloop van die projek was. Daar het ' $n$ betekenisvolle verbetering $(p<0,05)$ op die mikro-vlak by Groepe 1 en 2 groepe plaasgevind, asook op die makro-vlak en by die totale bemagtigingstatus by Groep 1 . Hierdie twee groepe was oor ' $n$ langer tydperk by die teikengroep se werksaamhede betrokke. Die meerderheid van die lede van die totale groep het 'n eie besigheid begin wat ' $n$ bewyse is van hul vermoë om die entrepreneuriese vaardighede met sukses toe te pas.

'n Nie-formele onderrigprogram kan dus, deur die toepassing van die PAR benadering, geïmplementeer word om vaardigheidsontwikkeling te fasiliteer met die oog op bemagtiging en inkomste-genering. Sodoende kan daar ' $n$ bydrae gelewer word tot die volhoubare ontwikkeling van plattelandse gemeenskappe.

\section{- Ms MJ Botha}

Unit for Religion and Development Research University of Stellenbosch

\section{- Ms ME van der Merwe}

Former Department of Consumer Science. University of Stellenbosch

- Ms A Bester

Master's student

Former Department of Consumer Science.I University of Stellenbosch

\section{- Dr RM Albertyn}

Centre for Higher and Adult Education

University of Stellenbosch 


\section{INTRODUCTION}

Poverty and unemployment are urgent problems in the rural areas of South Africa (Mahlati, 2000). Only 18\% of those who are formally employed in the agriculture sector are women and many others rely on irregular income from seasonal work (South Africa, Department of Labour, 2004:9). Entrepreneurship and training are encouraged by the South African government as a means to address the problem of unemployment (South Africa, Department of Labour, 2001:5,6). Social intervention programmes, specifically adult education programmes, are used in this regard as vehicles to transfer skills and knowledge. The emphasis is on an outcome of competence in life-skills, rather than one based on pure academic knowledge and technical skills alone (Robinson, 1994:38).

The holistic approach to social interventions aimed at alleviating poverty is therefore propounded. Ngwane et al (2002) state that although income-based poverty focuses on an important dimension of poverty, it only gives a partial picture of the many ways in which human lives can be blighted. General thinking on poverty eradication strategies focuses on the conceptualisation of poverty as multifaceted rather than on being due to lack of income alone (Chemhuru \& Nhamo, 2004:62). "Since income is not the sum total of human lives, the lack of it cannot be the sum total of human deprivation" (United Nations Development Programme (UNDP), 1998:25).

The Millennium Development Goals articulated at the Millennium Summit in 2000 state an aim of eradicating extreme poverty and hunger by 2015 (UNDP, 2003 in Chemhuru \& Nhamo, 2004:62). One of the greatest challenges facing South Africa is job creation and development of people's skills (Kotzé \& Staude, 1996). The emphasis on community development in South Africa today emanates from the Reconstruction and Development Programme (RDP) (South Africa, 1994: paragraph 1.3.3) conceptualised to bring about social development by means of a people-driven process. This process involves that communities must take responsibility for their own development. Communities have to be empowered to take charge of this development for the development to be sustainable (Tamsane, 1998:67).

Empowerment of the individual is the goal to strive for, with the act of developing, building and increasing power of individuals through their sharing of ideas and working together during training. One main focus of empowerment is to provide training so that individuals become less dependent on others for help, and be able to help them to lead a better life. However, empowerment and competence do not come naturally. Therefore development agencies in South Africa assist communities to bring about positive change in poverty reduction, employment creation, the provision of housing, recreational services, social security and welfare (Collins, 1999:19). Adoo-Adeku (2004:9) states that development partners, adult educators, researchers as well as planners have recognised that it is necessary to involve the poor in any programme that aims at poverty reduction strategies that would improve their lives.

The Department of Consumer Science: Foods, Clothing and Housing, at the University of Stellenbosch, launched the Development and Advancement of Rural Entrepreneurship (DARE) programme in 1999 - an entrepreneurial skills training programme following the Participatory Action Research (PAR) approach helping communities to address their training needs. The PAR approach is regarded as a strategy that facilitates empowerment as well as the development of entrepreneurial skills. DARE programme components include the training of entrepreneurs, the identification of resources and (where feasible) access to resources and support to entrepreneurs in establishing small businesses (Botha \& Van der Merwe, 1999:3). The intended outcomes of the programme are entrepreneurship and empowerment on the micro, interface and macro levels.

PAR has become a common approach to social programmes in South Africa (Mouton, 1996:37). This has been described as a process that combines three activities: research, education and action (Kerfoot \& Winberg, 1997:33). PAR has a dual objective namely to produce knowledge and action directly useful to a community and to empower people through the process of constructing and using their own knowledge (Swanepoel, 1997:153).

The DARE programme has been involved in training of entrepreneurs through a variety of projects in the rural towns of Darling, Stellenbosch, Montagu and Paarl in the Western Cape province of South Africa. This report gives an overview of the research on developing entrepreneurial skills in adults in Darling through PAR in a non-formal adult education programme (Bester, 2002). This research was conducted over a period of 15 months (March 2000 - June 2001).

\section{PURPOSE AND OBJECTIVES FO THE STUDY}

The purpose of the study was:

- To implement a skills-training project through a non-formal adult education programme following a PAR approach.

- To evaluate the non-formal adult education programme where a PAR approach was followed.

The specific objectives of the study were:

- To determine the needs of a community regarding skills training projects and to identify training projects;

- To present skills training projects through a nonformal adult education programme using a PAR approach;

- To monitor the implementation of PAR in the nonformal adult education programme;

- To evaluate the effect of the programme on the empowerment status of the participants;

- To evaluate the effect of the programme on the participants' application of entrepreneurial skills. 


\section{METHODOLOGY}

\section{Subjects}

A previously disadvantaged neighbourhood in Darling was identified. This neighbourhood has a community centre with a training hall where adult education programmes have been presented. The 28 participants in the skills training project were self-selected and formed the original sample for this study. These individuals reacted positively to an invitation via the community centre to participate in the Snowflake Bake for Profit skills training project. The final sample of 20 participated as three action groups for the skills training and formal evaluation.

\section{Intervention Programme}

An entrepreneurial skills training programme is a systematic plan of action to help individuals become entrepreneurs (Simanowitz, 1999). Snowflake Bake for Profit is a training course with the dual purpose of empowering individuals (the abstract goal) and equipping them with entrepreneurial skills (concrete goal) (Rigutto, 2001:1). Empowerment is defined as the process of increasing people's power or potential at the personal, interpersonal or political level by allowing them to initiate, be actively involved in and contribute to programmes aimed at improving their environment, their lives and of those around them (Tamasane, 1998:67). Entrepreneurship is defined as the process of doing something new and something different for the purpose of creating wealth for the individual and adding value to society (Johnsrud, 1997:22). Entrepreneurial skills are needed for an entrepreneur to establish a business.

The Snowflake Bake for Profit course consisted of six once-a-week daylong classes spread over a period of six weeks. The course included a theory section on business skills and a practical baking section with the aim to equip the participants to become professional bakers. The theoretical classes on business skills were alternated weekly with practical baking classes.

\section{Procedure}

To determine the interest in and needs of the commu- nity for adult education programmes dealing with entrepreneurial skills training and to identify suitable training projects (objective 1 ), interviews were conducted with interest groups from the community centre. The participants voluntarily attended one of three Snowflake Bake for Profit courses at the Bergzicht Training Centre in Stellenbosch. Each of these groups is referred to as action groups one to three indicating the courses attended during the research period. Data regarding the demographic details of respondents, educational qualifications, training experience, and interest in training was gathered from participants.

The PAR approach was applied to the target group consisting of the three action groups as they each joined the project at different times and focused on skills training and entrepreneurial development over a period of time (objective 2). PAR is a systematic research method that includes data gathering and constant feedback to the participants. The four stages of PAR, according to Zuber-Skerrit (1991:127), are planning, action, observation and reflection (Figure 1).

During planning, problems identified during the initial interview with the interest group were analysed and a strategic plan for the group of participants was developed. During the action phase, the strategic plan was implemented and the study group participated with the facilitator in the kind of action they agreed upon. The actions were monitored during the observation phase. This was followed with a reflection phase where all the participants gathered to reflect on their experience of the action that took place. They reviewed the outcomes of actions and how their needs were addressed. They identified new needs that emerged and a revised plan of action was discussed.

As recommended in PAR literature, the target group and the researchers identified problems together and solutions were sought as a group (Prozesky, 1998:2; Seymour-Rolls \& Hughes, 1998:2). They decided collectively on actions to address the problems and an action plan for the next phase was proposed. This revised plan became the first phase of the next plan of action. The length of the training cycles differed for the three groups and some of the cycles overlapped. Although this process is time consuming, the participants gain the opportunity to critically reflect on the

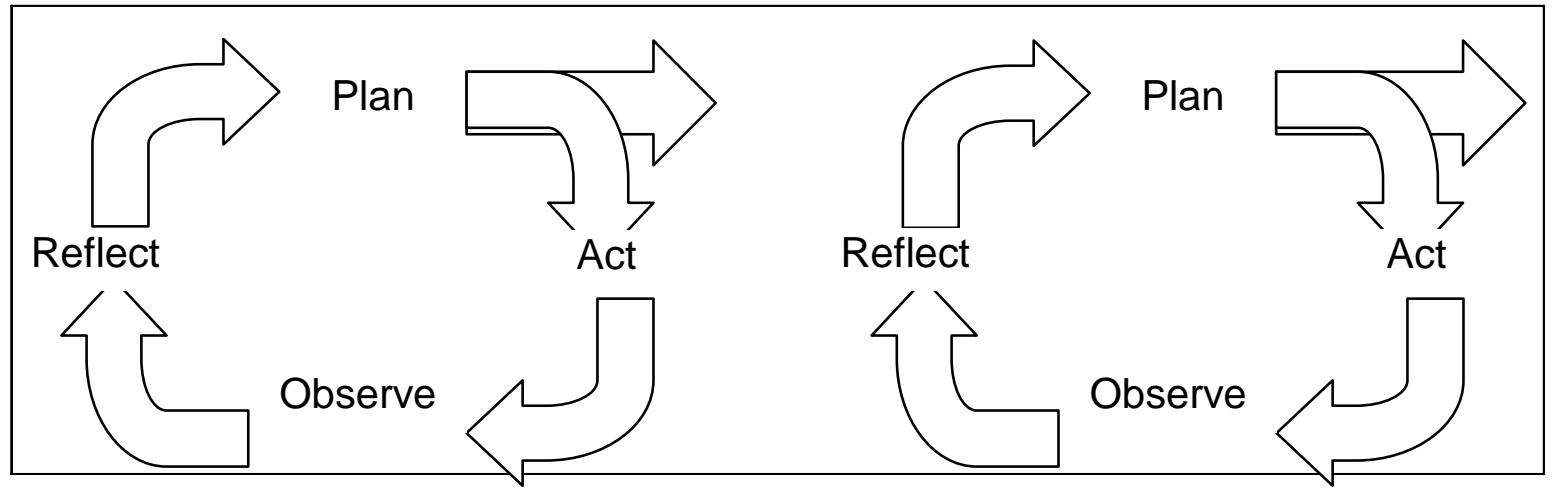

FIGURE 1: $\quad$ FOUR-MOMENT ACTION RESEARCH MODEL (Zuber-Skerritt, 1991:127) 
advantages and disadvantages of participation. Due to practical time constraints, this process continued for fifteen months.

\section{Measurement tools}

The process of implementing the non-formal adult education programme was monitored (objective 3 ) through informal interviews, as well as through the application of the PAR process. Criteria for monitoring the implementation of the programme during the action-reflection cycles were identified in the literature, namely the concepts of action, reflection and participation (Terre Blanche \& Durrheim, 1999:173; Walker, 1998:240). The researcher was not only a facilitator of the non-formal adult education programme, but also participant observer.

Quantitative data on the empowerment status of the participants (objective 4) was collected by using a standardised questionnaire, "Albertyn's Empowerment Questionnaire" (Albertyn, 2000:102-122). The questionnaire measures empowerment on three levels, namely the micro (personal) level, interface (interpersonal) level and macro (socio-political) level (Albertyn, 2005).

The successful application of entrepreneurial skills in the establishment of a business (objective 5) served as an indicator of a successful entrepreneurial skills programme as mentioned by Petrin (1997:12). In this study the successful application of entrepreneurial skills was measured by means of a semi-structured interview designed with the help of the Snowflake Bake for Profit training manual. The interview schedule was pilot tested and was applied as a post-test measure. Data was obtained regarding the participants' motivation for attending the DARE training programme, their perceptions of the project, the nature of the business they established and their application, or not, of the entrepreneurial skills taught in the programme. The qualitative data from the semi-structured interviews were analysed collectively as a group. At the time of the interview at the post-testing occasion, action Group $1(n=5)$ was part of the programme for almost twelve months, Group $2(n=12)$ joined later and thus participated for almost nine months and Group 3 $(n=7)$ for six months.

\section{Research design}

The questionnaire measuring empowerment was applied using the pre-post test protocol. The participants completed the questionnaires as a pre-test before they started one of the three Snowflake Bake for Profit skills training programmes and all of them completed the questionnaire as a post-test measure at the end of the research period ( 7 June 2001). The data from the questionnaire were statistically analysed by considering the frequency distribution of the mean scores of the three levels. Duncan's Multiple Range Test was applied to determine whether there was a statistically significant improvement in the empowerment score over time from the pre-test, prior to the non-formal adult education programme, to the post-test at the end of the research period. Each participant's pre-test and post-test scores were compared separately. The same was done with the scores of each group of participants and the scores of the study group as a whole.

The thematic framework according to criteria from PAR theory, namely the concepts of action, reflection and participation, was used to monitor and document the process and to analyse the qualitative data.

\section{RESULTS AND DISCUSSION}

\section{Needs}

While conducting interviews with interest groups from the community centre, the following needs were identified: available adult education programmes for skills training, trainers who have the skills and capacity to teach these programmes and people with entrepreneurial skills who could make and sell good quality products for tourists. It was noted by the respondents that Darling had a largely untapped tourism potential. The Snowflake Bake for Profit programme was identified as a viable training project that was acceptable to the target group.

Informal interviews with the members of the target group provided demographic information of the group. The self-selected group of participants who voluntarily joined one of three Snowflake Bake for Profit training courses in Stellenbosch were mostly females (18 females; 2 males) between the ages of 19 and 58. Six participants were formally employed and those who were unemployed at the stage when the research was conducted, performed domestic chores and cared for children and the elderly. The youngest participants had the highest average level of education. Other nonformal training that participants had undergone was noted by seven of the respondents and these related to training other than entrepreneurship training. The participants who attended the first contact session responded to the need for entrepreneurial skills training and not necessarily to the need to learn how to bake, although baking was noted most frequently as a motivation for joining the group.

\section{Skills training and development}

The motivation for this research was to improve the lives of individuals by helping them to develop entrepreneurial skills that might lead to income generation. During the PAR process, participants had control over the planning phase and decided collectively on activities they wanted to participate in. Three groups participated in the different Snowflake Bake for Profit training courses and at the completion of the course they joined the target group in the PAR process where further projects were identified. Participants did not always have the same interests and needs. Back-up plans were in place during the planning stage to resolve problems in the event of boredom or conflict and to ensure that all participants were satisfied. The PAR process in this study as illustrated in Figure 2 indicates the progression of activities as they proceeded during the 15-month research period. 


\begin{tabular}{|l|l|}
\hline \multicolumn{2}{|l|}{} \\
\cline { 2 - 2 }
\end{tabular}

FIGURE 2: IMPLEMENTATION OF PAR PROCESS IN DARLING

\section{Monitoring}

Criteria for monitoring the implementation of the programme during the cycles were action, reflection and participation. Most of the cycles centred on actions relating to the establishment of a business. During reflection participants found solutions to problems that they experienced during the previous action phase and planned for the next action that took place. These reflection meetings promoted critical reflexive inquiry and produced knowledge that the participants could use in practical problem solving. The Darling Focus holiday project and training of the Darling Focus committee were evidence that reflection by the target group resulted in new as well as revised plans of action. Participation meant involvement of participants in all stages of the research. It was a collaborative effort between the facilitator and the participants. A high degree of participation was encouraged through feedback sessions and problem solving was a collective effort. The participants were involved in formative evaluation at an informal level during the PAR process.

\section{Empowerment status evaluation}

The findings from the statistical analysis of the quantitative data on the empowerment status of the 20 respondents who completed both the pre- and post-test empowerment questionnaires revealed that there was an improvement in the overall empowerment status of the participants from the pre-test $(69,4 \%)$ to the posttest $(76,1 \%)$ (Table1). The greatest improvement was reflected at the micro-level of empowerment (personal empowerment), which represents the individual's sense or feelings of control over his/her specific environment and over the direction of his/her own life. This positive change indicates that the participants felt more in control of their lives, which related to their belief in personal success, self-worth and competence.

Statistically significant $(p<0,05)$ changes were observed in the group's micro-, macro- and total levels of empowerment over time. At the macro-level, which is the individuals' power to effect political, economic or social changes in their immediate environment, the increase in the group's level of empowerment shows 
TABLE 1: $\quad$ EMPOWERMENT STATUS AT PRE- AND POST-TESTING OCCASIONS

\begin{tabular}{|l|c|c|c|c|c|c|c|c|}
\cline { 2 - 9 } \multicolumn{1}{c|}{} & \multicolumn{2}{c|}{$\begin{array}{c}\text { Total Group } \\
\text { (N=20) }\end{array}$} & \multicolumn{2}{c|}{$\begin{array}{c}\text { Action Group 1 } \\
\text { (n=5) }\end{array}$} & \multicolumn{2}{c|}{$\begin{array}{c}\text { Action Group 2 } \\
(\mathbf{n = 8})\end{array}$} & \multicolumn{2}{c|}{$\begin{array}{c}\text { Action Group 3 } \\
(\mathbf{n}=\mathbf{7})\end{array}$} \\
\hline $\begin{array}{l}\text { Level of } \\
\text { Empowerment }\end{array}$ & $\begin{array}{c}\text { Pre } \\
\%\end{array}$ & $\begin{array}{c}\text { Post } \\
\%\end{array}$ & $\begin{array}{c}\text { Pre } \\
\%\end{array}$ & $\begin{array}{c}\text { Post } \\
\%\end{array}$ & $\begin{array}{c}\text { Pre } \\
\%\end{array}$ & $\begin{array}{c}\text { Post } \\
\%\end{array}$ & $\begin{array}{c}\text { Pre } \\
\%\end{array}$ & $\begin{array}{c}\text { Post } \\
\%\end{array}$ \\
\hline Micro-level & 68,8 & $77,2^{*}$ & 71,5 & $80,8^{\star}$ & 68,8 & $77,6^{*}$ & 66,8 & 74,1 \\
\hline Interface level & 71,2 & 75,4 & 72,7 & 77,3 & 69,0 & 75,0 & 72,6 & 74,5 \\
\hline Macro-level & 68,8 & $74,2^{*}$ & 68,5 & $77,3^{\star}$ & 68,3 & 73,8 & 69,8 & 72,5 \\
\hline Total & 69,4 & $76,1^{*}$ & 71,1 & $79,2^{*}$ & 68,7 & 76,1 & 68,9 & 73,9 \\
\hline
\end{tabular}

* Significant $(p<0,05)$ improvement at the post measurement

that they believe more strongly that they can contribute to society and bring about social change. Empowerment on the interface (interpersonal) level, which refers to the ability to act collectively to solve problems, appears to require more time to manifest than on the micro- and macro-levels. It seems that they must first have a greater understanding of their own lives before they can transform or intervene in the public realm.

All three of the action groups had an increase in their empowerment scores by the end of the research period. However, there was a positive correlation between the length of time that a group was involved in the programme and the extent of the change in their empowerment scores. A significant improvement $(p<0,05)$ occurred in Group 1's (12 month involvement) micro-level, macro-level and total score of empowerment between the two testing occasions. In the case of Group 2 (9 months involvement) only the micro-level score improved significantly $(p<0,05)$. No significant differences were noted in the scores of Group 3 (6 months involvement) over time.

\section{Evaluation of entrepreneurial skills}

In this study the successful application of entrepreneurial skills was measured by means of a semistructured interview at a post-testing occasion. The majority of participants' motivation for attending the DARE training programme was to learn more about baking (43\%). Participants perceived the non-formal adult education programme as generally successful. Twelve participants (57\%) were motivated by intrinsic rewards to attend the non-formal adult education training programme. Intrinsic rewards are associated with the satisfaction of learning, gaining insight and acquiring new knowledge. The highest frequency of responses (39\%) regarding which aspect of the course the participants liked the most, was found to be the practical baking section of the Snowflake Bake for Profit skills training. This illustrates the participantoriented model of evaluation (lowa State University, 1999). Some of the participants experienced difficulty with the theory of the business skills training, as they did not have a high level of education. It is encouraging that the participants who attended the Snowflake Bake for Profit skills training had established microbusinesses at the time of the final interviews. The majority ran their businesses from their own homes $(70 \%)$ and used their own equipment $(60 \%)$. A reason for this success could be that this specific training project was more hands-on and combined the theory of business skills with the practical training skills of baking. This integrated approach to teaching ensures that learning is reinforced through practical application within their natural daily environment thus developing self-esteem, which is one of the principles of empowerment (Albertyn, 2000:51).

\section{CONCLUSIONS AND RECOMMENDATIONS}

In response to the challenges facing those with limited resources, especially in rural areas in South Africa, the motivation of this research was to improve the lives of individuals by helping them to develop entrepreneurial skills that might lead to income generation. Following an approach that would involve including the participants in the process of their own learning should enhance their perception of their empowerment status.

In Darling there was a need for and an interest in nonformal adult education programmes that specialise in skills training and entrepreneurial development leading to income generation. The non-formal adult education programmes using PAR appeared to be a successful approach in transferring skills due to the active involvement of participants in the process of planning and learning. The findings revealed that the requirements for PAR namely action objectives, critical reflection and participation were met. Planning and actions were revised according to the needs of the participants, integrated with continual reflection in the group context, as well as subsequent adaptation and application in further actions. The programme's intended outcome of empowerment of the participants in the programme had been achieved. Participation in this non-formal adult education programme resulted in a positive change in the overall empowerment status of the participants. The greatest change occurred on the micro- (personal) level of empowerment. The majority of the participants in this training project applied the entrepreneurial skills that they were taught in establishing their own businesses.

Application of PAR focuses on the individual within the community and ensures that ownership is placed within the target group. Problems may arise due to varying needs of individuals, which could provide challenges in the process of conducting research, especially within a restricted time frame. In this study, for example, some participants only wanted to learn how 
to bake and did not necessarily want to pursue an entrepreneurial path. Other participants wanted to acquire business skills, but were not particularly interested in baking. Most people generally have some skills they can use to generate an income, but this does not mean that they will actually use this skill in an entrepreneurial fashion. Thus the outcome of income generation as stated in the motivation for this study may not have been met in all cases in the group.

The use of the PAR approach when facilitating training programmes within communities seems, however, to be an effective strategy to empower participants. The fact that group members participate in the process of their own development assists in bolstering their individual self-esteem and providing an opportunity to develop their confidence when applying the skills learned within their own reality. PAR is conducted within the supportive network of a group setting and this helps to facilitate empowerment of the individuals. The process of continual critical reflection and adaptation according to identified needs are, in themselves, life-skills that can be learned in this integrated approach. Further research could investigate the longterm effect of engaging with a target group in a rural community where facilitation of individual skills is encouraged using a PAR approach.

It appears that the PAR approach aimed at holistic development of individuals could be used in facilitating non-formal adult education programmes, such as the entrepreneurial programme in this study, and in so doing make a contribution to sustainable development in rural communities.

\section{REFERENCES}

ADOO-ADEKU, K. 2004: Gender poverty and sustainable environmental management: a Ghanaian experience. International conference. Education and poverty reduction: a global responsibility. Proceedings. Gaberone. Botswana. June 2004.

ALBERTYN, RM. 2005. Increased accountability through monitoring empowerment programmes. Journal of Family Ecology and Consumer Sciences 33: 3136.

ALBERTYN, RM. 2000. Conceptualisation and measurement of empowerment of workers: an educational perspective. PhD dissertation. Stellenbosch. University of Stellenbosch.

BESTER, A. 2002. A participatory action research approach to programme evaluation in a rural society. Unpublished Master's thesis. Stellenbosch. University of Stellenbosch.

BOTHA, MJ \& VAN DER MERWE, ME. 1999. DAREprogramme: Proposal for funding. Stellenbosch. University of Stellenbosch.

CHEMHURU, S \& NHAMO, G. 2004. Macroeconomics, adult education and poverty eradication: examples from Southern Africa. International conference. Education and poverty reduction: a global responsibility. Proceedings. Gaberone. Botswana. June 2004.
COLLINS, K. 1999. Participatory research: a primer. Pretoria. Prentice-Hall.

IOWA STATE UNIVERSITY. 1999. WEBCT. Available on line. URL: http://www.webct.cc.iastate.edu. Accessed 8 December 1999.

JOHNSRUD, MD. 1997. Entrepreneurship in the development of a rural area. In Petrin, T \& Gannon, A. 1997. Rural development through entrepreneurship. Rome. FAO.

KERFOOT, C \& WINBERG, C. 1997. Learning about action research. Cape Town. Juta.

KOTZÉ, C \& STAUDE, G. 1996. The development of and andragogic training programme for small business retailers. Development Southern Africa 13(1): 101-108.

MAHLATI, V. 2000. Struggle for survival: rural poverty. Enterprise: networking for Africa's entrepreneurs and leaders 145: 46-47.

MOUTON, J. 1996. Understanding social research. Pretoria. Van Schaik.

NGWANE, AK, YADAVALLI, VSS \& STIFFENS, FE. 2002. Poverty: deprivations in terms of basic needs. Development Southern Africa 19(4):545-560.

PETRIN, T. 1997. Entrepreneurial development process; a training approach. In Petrin, T \& Gannon, A. 1997. Rural development through entrepreneurship. Rome. FAO.

PROZESKY, HE. 1998. The principles and characteristics of PAR. Unpublished Master's thesis. Stellenbosch. University of Stellenbosch.

RIGUTTO, L. 2001. Message from Luiza. Phumelela 1:1.

ROBINSON, RD. 1994. An introduction to helping adults learn and change. 2nd ed. West Bend. Omnibook.

SOUTH AFRICA. 1994. Reconstruction and development programme. White paper. Cape Town. Government Printer.

SOUTH AFRICA. DEPARTMENT OF LABOUR. 2004. Employment equity analysis report. Available on line. URL: http://www.labour.gov.za. Accessed 6 July 2006.

SOUTH AFRICA. DEPARTMENT OF LABOUR. 2001. National Skills Development Strategy: Setting the context in Department of Labour, National Skills Development Strategy: Leadership Pack. Pretoria. Government Printer.

SEYMOUR-ROLLS, K \& HUGHES, I. 1998. Participatory Action Research: getting the job done. Available online. URL: http://www.cchs/usyd.edu.au/arow/ reader/hughes3.htm. Accessed 10 July 2001.

SIMANOWITZ, A. 1999. Effective strategies for reaching the poor. Development Southern Africa 16(1):169181.

SWANEPOEL, H. 1997. Community Development. Putting plans into action. 3rd ed. Cape Town. Juta.

TAMASANE, TA. 1998. Community empowerment through participation: a South African small town case study. Unpublished Master's thesis. Stellenbosch. University of Stellenbosch.

TERRE BLANCHE, M \& DURRHEIM, K. (eds) 1999.

Research in practice. Cape Town. University of Cape Town Press.

UNITED NATIONS DEVELOPMENT PROGRAMME (UNDP). 1998. Human development report 1998. 
New York. Oxford University Press.

WALKER, M. 1998. Evaluation. Methods for studying

programs and policies. 2nd ed. Upper Saddle River.

Prentice-Hall.
ZUBER-SKERRITT, O (ed). 1991. Action research for change and development. Vermont. Gower Publishing. 